\title{
18F-FDG PET/CT in Patients with Vulvar and Vaginal Cancer: A Preliminary Study of 20 Cases
}

\author{
18F-FDG PET/TC em Doentes com Carcinoma da Vulva e Vagina: \\ Estudo Preliminar de 20 Casos
}

\author{
Patrícia GOUVEIA $\triangle^{1}$, Adriana SÁ PINTO² ${ }^{2}$ Liliana VIOLANTE³ ${ }^{3}$ Sara NUNES ${ }^{4}$, Ricardo TEIXEIRA ${ }^{1}$, Almerinda PETIZ $^{5}$, \\ Luís Hugo DUARTE ${ }^{2}$ \\ Acta Med Port 2022 Mar;35(3):170-175 - https://doi.org/10.20344/amp.12510
}

\section{ABSTRACT}

Introduction: Despite the growing evidence supporting the use of 2-[F-18]-fluor-2-desoxi-D-glucose positron emission tomography/ computed tomography in cervical and ovarian malignant tumours, data on vulvar and vaginal cancer is sparse. Our aim was to assess the role of 2-[F-18]-fluor-2-desoxi-D-glucose positron emission tomography/computed tomography in patients with vulvar and vaginal cancer.

Material and Methods: A retrospective study was conducted on a cohort of 20 patients with biopsy-proven vulvar $(n=17)$ and vaginal $(n=3)$ cancer who performed 2-[F-18]-fluor-2-desoxi-D-glucose positron emission tomography/computed tomography, between January 2013 and April 2018. We collected the clinical data of all patients, as well as the indication for 2-[F-18]-fluor-2-desoxi-D-glucose positron emission tomography/computed tomography, its results, and the main lesion maximum standard uptake value (SUVmax). In addition, we correlated the results of 2-[F-18]-fluor-2-desoxi-D-glucose positron emission tomography/computed tomography with other diagnostic modalities, namely histological findings, computed tomography and magnetic resonance imaging. Patients were divided into two groups, one with newly diagnosed disease and another with recurrent disease.

Results: Six patients had newly diagnosed disease and 14 had recurrent disease. The main lesion was detected by 2-[F-18]-fluor2-desoxi-D-glucose positron emission tomography/computed tomography in five out of six patients with newly diagnosed disease and in all 14 patients with recurrent disease. Additional sites of 2-[F-18]-fluor-2-desoxi-D-glucose uptake were identified in inguinal and iliac lymph nodes and in distant lesions. Magnetic resonance imaging and computed tomography were performed in 12 cases. In four patients with recurrent disease, abnormalities (main lesion/ metastatic lymph nodes) identified by 2-[F-18]-fluor-2-desoxi-D-glucose positron emission tomography/computed tomography were not detected as suspicious by computed tomography.

Conclusion: In this preliminary study, 2-[F-18]-fluor-2-desoxi-D-glucose positron emission tomography/computed tomography demonstrated it can be a useful method in patients with vulvar and vaginal cancers, namely in defining the extent of disease and contributing to accurate staging and restaging.

Keywords: Fluorodeoxyglucose F18; Positron Emission Tomography Computed Tomography; Vaginal Neoplasms/diagnostic imaging; Vulvar Neoplasms/diagnostic imaging

\section{RESUMO}

Introdução: Apesar da crescente evidência que suporta o uso da tomografia por emissão de positrões/ tomografia computorizada com 2-[F-18]-fluor-2-desoxi-D-glucose em tumores malignos do colo do útero e do ovário, os dados sobre o carcinoma da vulva e da vagina são escassos. O nosso objetivo foi avaliar o papel da tomografia por emissão de positrões/ tomografia computorizada com 2-[F-18]-fluor-2-desoxi-D-glucose em doentes com carcinoma da vulva e da vagina.

Material e Métodos: Entre janeiro de 2013 e abril de 2018 foi realizado um estudo retrospetivo numa coorte de 20 doentes com carcinoma da vulva $(n=17)$ e da vagina $(n=3)$, comprovados por biópsia, que efetuaram tomografia por emissão de positrões/ tomografia computorizada com 2-[F-18]-fluor-2-desoxi-D-glucose. Recolheram-se os dados clínicos de todos os doentes, bem como a indicação clínica para a realização da tomografia por emissão de positrões/ tomografia computorizada com 2-[F-18]-fluor-2-desoxi-D-glucose, os seus resultados e o valor de captação padronizado máximo da lesão principal (SUVmax). Para além disso, correlacionaram-se os resultados da tomografia por emissão de positrões/ tomografia computorizada com 2-[F-18]-fluor-2-desoxi-D-glucose com os de outras modalidades diagnósticas, nomeadamente com os achados histológicos, a tomografia computadorizada e a ressonância magnética. Os doentes foram divididos em dois grupos, um com doença recém diagnosticada e outro com doença recorrente.

Resultados: Seis doentes tinham doença recém diagnosticada e 14 tinham doença recorrente. A lesão principal foi detetada em cinco dos seis doentes com doença recém diagnosticada e nos 14 com doença recorrente. Foram identificados outros locais de captação de 2-[F-18]-fluor-2-desoxi-D-glucose, nomeadamente gânglios linfáticos ilíacos e inguinais, e lesões à distância. Em 12 casos foram realizadas ressonância magnética e tomografia computorizada. Em quatro casos com doença recorrente, as anomalias (lesão principal / gânglios linfáticos metastáticos) identificadas na tomografia por emissão de positrões/ tomografia computorizada com 2-[F-18]-fluor-2-desoxi-D-glucose não haviam sido descritas como suspeitas pela tomografia computorizada.

Conclusão: Neste estudo preliminar, a tomografia por emissão de positrões/ tomografia computorizada com 2-[F-18]-fluor-2-desoxi-D-glucose demonstrou poder ser um método útil em doentes com carcinoma da vulva e da vagina, nomeadamente na definição da extensão da doença e na contribuição para o estadiamento e restadiamento precisos.

1. Serviço de Medicina Nuclear. Centro Hospitalar do Porto. Porto. Portugal.

2. Serviço de Medicina Nuclear. Centro Hospitalar de São João. Porto. Portugal.

3. Serviço de Medicina Nuclear. Instituto Português de Oncologia do Porto. Porto. Portugal.

4. Serviço de Ginecologia e Obstetrícia. Centro Hospitalar de Trás-os-Montes e Alto Douro. Vila Real. Portugal.

5. Clínica de Ginecologia. Instituto Português de Oncologia do Porto. Porto. Portugal.

$\triangle$ Autor correspondente: Patrícia Gouveia. patriciabarrosgouveia@hotmail.com

Recebido: 04 de julho de 2019 - Aceite: 07 de maio de 2020 - First published: 24 de novembro de 2021 - Online issue published: 02 de março de 2022

Copyright @ Ordem dos Médicos 2022 
Palavras-chave: Fluordesoxiglucose F18; Neoplasias Vaginais/diagnóstico por imagem; Neoplasias Vulvares/diagnóstico por imagem; Tomografia Computorizada com Tomografia por Emissão de Positrões

\section{INTRODUCTION}

Vaginal and vulvar cancers are rare, accounting for $1 \%$ $-4 \%$ of all gynaecological malignancies. ${ }^{1}$ The majority of cases are seen in postmenopausal elderly women and the most common histological subtype is squamous cell carcinoma. ${ }^{2,3}$ These tumours are staged according to the International Federation of Obstetrics and Gynaecology (FIGO) staging system. ${ }^{4,5}$ Typical patterns of disease spread include local invasion and lymphatic dissemination. ${ }^{6,7}$

There is growing evidence supporting the use of 2-[F-18]-fluor-2-desoxi-D-glucose positron emission tomography/computed tomography (18F-FDG PET/CT) in gynaecologic malignancies. This technique is already used to stage, to monitor response and to detect recurrent disease in patients with cervical and ovarian cancer. ${ }^{8}$ However, data on the role of $18 \mathrm{~F}-\mathrm{FDG}$ PET/CT in vulvar and vaginal cancer is sparse.

The aim of this study was to assess 18F-FDG PET/CT role in patients with vulvar and vaginal cancers.

\section{MATERIAL AND METHODS \\ Study design and participants}

We retrospectively analysed 20 patients with biopsyproven vulvar $(n=17)$ and vaginal $(n=3)$ cancer who underwent 18F-FDG PET/CT in an oncology center, between January 2013 and April 2018. Demographic and clinical data of patients was collected, namely age when undergoing 18F-FDG PET/CT, histological findings, FIGO staging and previous treatments. The indication for 18F-FDG PET/ $\mathrm{CT}$, main lesion maximum standard uptake value (SUVmax) and final results were registered. In addition, 18F-FDG $\mathrm{PET} / \mathrm{CT}$ results were correlated with computed tomography (CT) and magnetic resonance imaging (MRI). CT or MRI scans were performed within three months of the 18F-FDG $\mathrm{PET} / \mathrm{CT}$ and no therapeutic interventions were carried out between these tests. Patients were divided into two groups, one with newly diagnosed disease and other with recurrent disease.

This study was approved by the Ethics Committee of Instituto Português de Oncologia do Porto (CES IPO: 373R/019).

\section{PET imaging}

Images were acquired on a Biograph 6 True Point in 14 patients and on a Biograph $20 \mathrm{mCT}$ Flow with added time-of-flight technology (Siemens Healthcare, Erlangen, Germany) in six patients. Patients were instructed to fast for six hours prior to the intravenous administration of $18 \mathrm{~F}$ FDG (median administered activity $343.3 \mathrm{MBq}$, IQR 97.03). Blood glucose levels were lower than $200 \mathrm{mg} / \mathrm{dL}$ at the time of the tracer injection. All patients were orally hydrated and asked to empty their bladder before image acquisition. Images were acquired 60 minutes after radiopharmaceutical injection, from mid-thigh to vertex. Image acquisition was performed in supine position. CT was performed first, with no breath-hold, a section width of $3 \mathrm{~mm}$ and standard window reconstruction. Exposure factors were modulated automatically, using $120 \mathrm{KeV}$ as reference and 30-60 mAs. PET was performed in 3D mode. 'Step-and-shoot' PET images were acquired on the Biograph 6 system $(15 \mathrm{~cm}$ beds, $3 \mathrm{~min} / \mathrm{bed}, 7$ - 8 beds) and continuous table motion PET acquisition was performed on the Biograph 20 system $(1.1-1.5 \mathrm{~mm} / \mathrm{s})$. Image reconstruction procedures included attenuation and scatter correction, ordered subset expectation maximization (OSEM) and Gaussian filter application.

\section{Image analysis}

18F-FDG PET/CT images were evaluated by two nuclear medicine physicians. In case of lack of agreement, a third element was consulted.

The PET images were analysed visually and semiquantitatively by measuring the SUVmax. Suspicious abnormal focus of 18F-FDG uptake were considered 'positive' for lesions (main lesion/secondary lesion). Main lesions SUVmax was measured by drawing a region of interest (ROI) over the area of maximum activity and was calculated as the highest SUV of the pixels within the ROI.

\section{RESULTS}

Seventeen vulvar cancer patients and three vaginal cancer patients were studied. All patients had squamous cell carcinoma. The mean age of the sample was $69.1 \pm$

Table 1 - Clinical data, histologic findings, 18F-FDG PET/CT, CT and MRI of newly diagnosed patients

\begin{tabular}{|c|c|c|c|c|c|c|c|c|c|c|c|c|}
\hline \multirow[b]{2}{*}{$\begin{array}{l}\text { Patient } \\
\text { number }\end{array}$} & \multirow[b]{2}{*}{$\begin{array}{c}\text { Test } \\
\text { indication }\end{array}$} & \multirow[b]{2}{*}{$\begin{array}{l}\text { Figo } \\
\text { stage }\end{array}$} & \multicolumn{5}{|c|}{ Primary tumour } & \multicolumn{5}{|c|}{ Metastasis } \\
\hline & & & Biopsy & PET & CT & MRI & Location & Biopsy & PET & CT & MRI & Location \\
\hline 1 & Staging & I & $(+)$ & $(-)$ & ND & ND & Vulva & ND & $(-)$ & ND & ND & \\
\hline 2 & Staging & II & $(+)$ & $(+)$ & ND & ND & Vulva & ND & $(+)$ & ND & ND & IN \\
\hline 3 & Staging & IV & $(+)$ & $(+)$ & $(+)$ & ND & Vulva & $(+)$ & $(+)$ & $(+)$ & ND & IL, IN \\
\hline 4 & Staging & II & $(+)$ & $(+)$ & ND & $(+)$ & Vagina & ND & $(-)$ & ND & $(-)$ & \\
\hline 5 & Staging & IV & $(+)$ & $(+)$ & $(+)$ & $(+)$ & Vagina & ND & $(+)$ & $(+)$ & $(+)$ & IL, IN \\
\hline 6 & Staging & II & $(+)$ & $(+)$ & ND & $(+)$ & Vagina & ND & $(-)$ & ND & $(-)$ & \\
\hline
\end{tabular}

PET: positron emission tomography; CT: computed tomography; MRI: magnetic resonance imaging; (-): negative for malignancy; ND: not done; (+): positive for malignancy; IL: iliac lymph nodes; IN: inguinal lymph nodes 
11.7 years old. Six patients had newly diagnosed disease and 14 had recurrent disease.

\section{Newly diagnosed cancer}

Six patients were evaluated as part of pre-treatment assessment and18F-FDG PET/CT was requested to stage these patients.

Clinical data, histological findings, 18F-FDG PET/CT, $\mathrm{CT}$ and MRI of newly diagnosed patients are displayed in Table 1.

The six patients with newly diagnosed disease were clinically classified as FIGO I, II and IV. Histological confirmation of the primary tumour was obtained in all patients. Histological confirmation of metastatic disease was obtained in one patient.

The primary tumour was detected by $18 \mathrm{~F}-\mathrm{FDG}$ PET/CT in five out of six patients (median SUVmax 6.5 [ $\mathrm{min}=6.0$; $\max =18.7]$ ) - Figs. 1 and 2 . The patient with negative $18 \mathrm{~F}$ FDG primary cancer had a clinical stage of I and performed the technique on Biograph 6 True Point. 18F-FDG PET/CT identified suspicious metastatic lymph nodes in three cases (inguinal and iliac).

CT studies were performed in two patients. CT detected the primary tumour and positive lymph nodes in the two cases.

Three patients underwent MRI. The primary tumour was identified in all three MRI studies and positive lymph nodes (inguinal and iliac) in one case.

CT was in agreement with 18F-FDG PET/CT in both cases (2/2) and MRI in all cases (3/3), in the evaluation of the primary tumour and metastasis.

\section{Recurrent disease}

Fourteen patients had previously underwent surgery: hemivulvectomy $(n=4)$, radical vulvectomy $(n=6)$ and vulvectomy with pelvic lymph node dissection $(n=4)$. Four of these patients were being treated with chemotherapy.

18F-FDG PET/CT was requested to restage 10 patients (nine patients had vulvar recurrence on routine follow-up examination and one had clinically suspected metastatic disease) and to evaluate treatment response in four patients under chemotherapy.

Table 2 describes the clinical data, histologic findings, 18F-FDG PET/CT, CT and MRI of patients with recurrent disease.

The original clinical stage of the 14 patients with recurrent disease was FIGO I, II and III, respectively. Histological confirmation of the recurrent tumour was obtained in all patients. Histological confirmation of metastatic disease was obtained in three patients.

The recurrent main lesion was detected by $18 \mathrm{~F}-\mathrm{FDG}$ $\mathrm{PET} / \mathrm{CT}$ in all patients [median SUVmax $9.3(\mathrm{~min}=6.2$; $\max$ = 50.6)]. 18F-FDG PET/CT identified suspicious metastatic lymph nodes (exemplified on Fig. 3) in five studies (inguinal and iliac) and distant metastases (lung and subcutaneous tissue of the thigh) in two.

CT studies were performed in four patients. CT detected recurrent disease in three cases. Suspicious metastatic

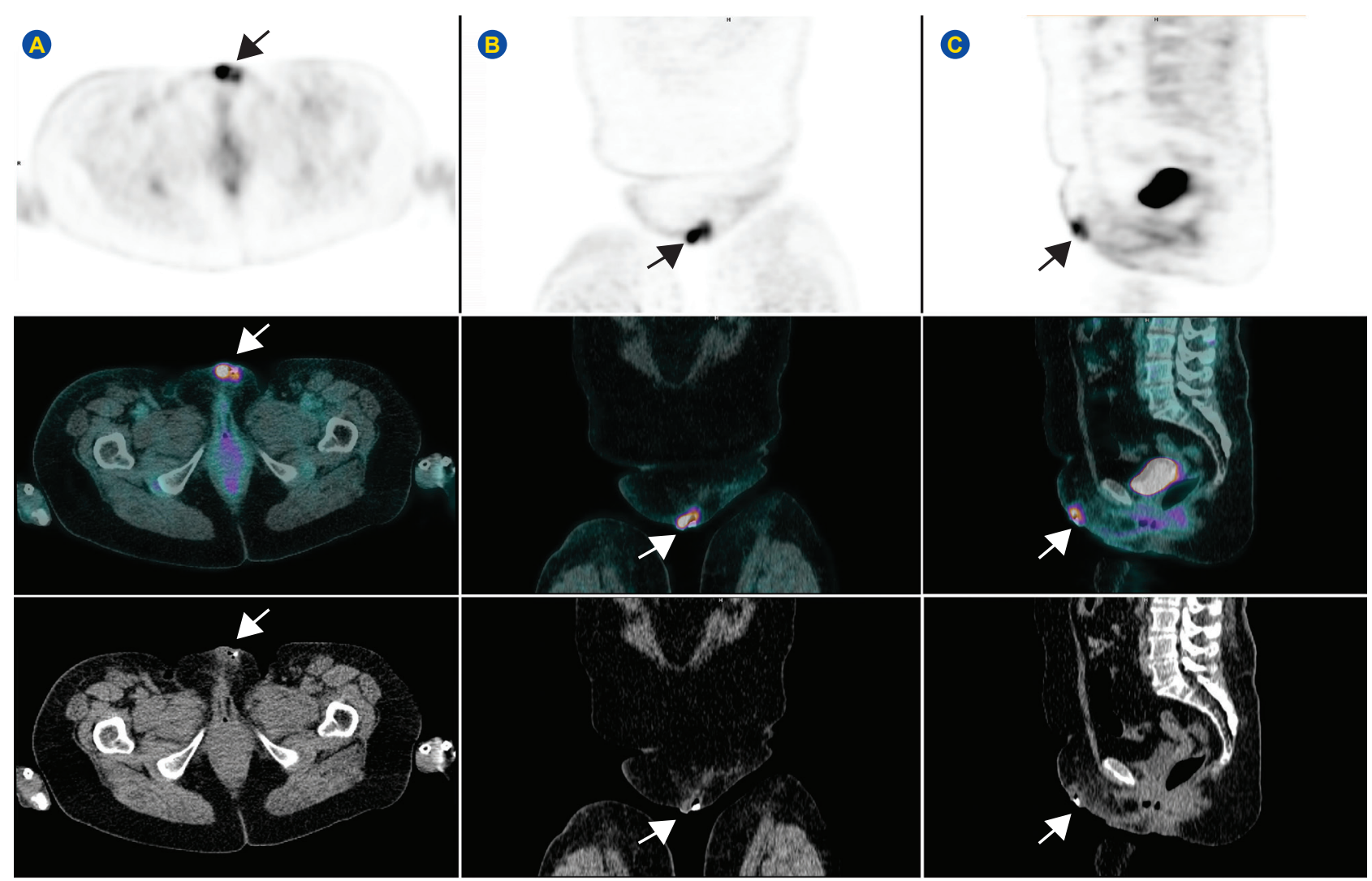

Figure 1 - Intense 18F-FDG activity in primary vulvar cancer (arrows on PET, PET/CT and CT in axial A, coronal B, and sagittal C planes) 


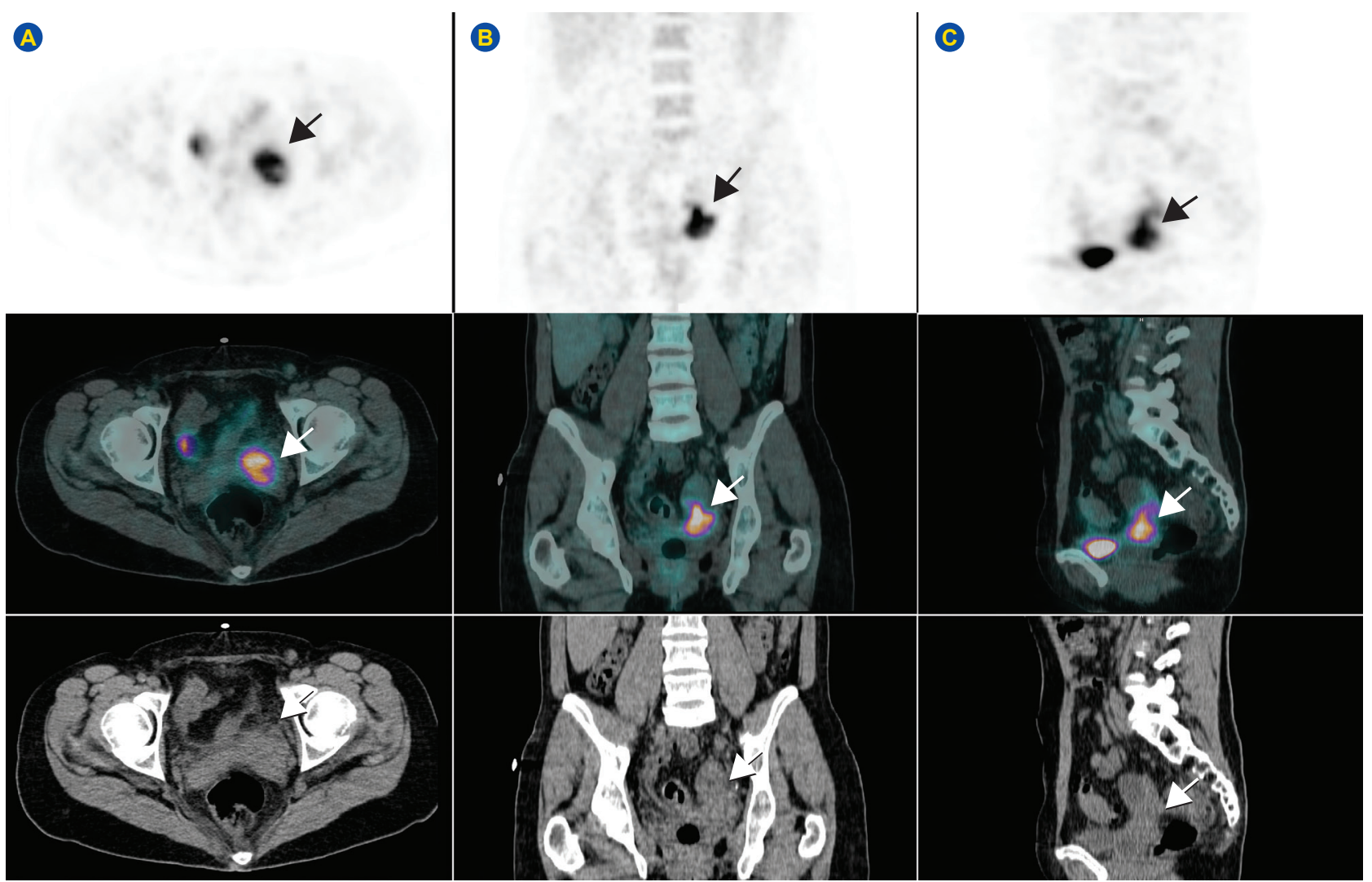

Figure 2 - Increased 18F-FDG uptake in primary vaginal cancer (arrows on PET, PET/CT and CT in axial A, coronal B, and sagittal C planes)

disease was not detected by CT.

Three patients underwent MRI. The recurrent tumour was identified in three MRI studies. Suspicious metastatic disease was not identified on MRI.

Regarding the recurrent main lesion, CT was in agreement with 18F-FDG PET/CT in three cases (3/4). In one case, the recurrent tumour detected on 18F-FDG PET/CT was not considered suspicious in CT. MRI was in agreement with 18F-FDG PET/CT in all cases (3/3).

Regarding the detection of metastasis, CT was in agreement with 18F-FDG PET/CT in 1 case (1/4). In the other three cases, metastatic lymph nodes identified by 18 F-FDG

Table 2 - Clinical data, histologic findings, 18F-FDG PET/CT, CT and MRI of patients with recurrent disease

\begin{tabular}{|c|c|c|c|c|c|c|c|c|c|c|c|c|}
\hline \multirow[b]{2}{*}{$\begin{array}{l}\text { Patient } \\
\text { number }\end{array}$} & \multirow[b]{2}{*}{$\begin{array}{c}\text { Test } \\
\text { indication }\end{array}$} & \multirow[b]{2}{*}{$\begin{array}{l}\text { Figo } \\
\text { stage }\end{array}$} & \multicolumn{5}{|c|}{ Recurrent tumour } & \multicolumn{5}{|c|}{ Metastasis } \\
\hline & & & Biopsy & PET & CT & MRI & Location & Biopsy & PET & CT & MRI & Location \\
\hline 7 & $\mathrm{R}$ & III & $(+)$ & $(+)$ & ND & ND & Vulva & ND & $(-)$ & ND & ND & \\
\hline 8 & $\mathrm{R}$ & III & $(+)$ & $(+)$ & $(+)$ & ND & Vulva & ND & $(+)$ & $(-)$ & ND & IL \\
\hline 9 & $\mathrm{R}$ & 1 & $(+)$ & $(+)$ & ND & $(+)$ & Vulva & ND & $(-)$ & ND & $(-)$ & \\
\hline 10 & $\mathrm{R}$ & III & $(+)$ & $(+)$ & $(-)$ & $(+)$ & Vulva & ND & $(-)$ & $(-)$ & $(-)$ & \\
\hline 11 & $\mathrm{R}$ & II & $(+)$ & $(+)$ & ND & ND & Vulva & ND & $(-)$ & ND & ND & \\
\hline 12 & $\mathrm{R}$ & I & $(+)$ & $(+)$ & ND & ND & Vulva & ND & $(-)$ & ND & ND & \\
\hline 13 & $\mathrm{R}$ & 1 & $(+)$ & $(+)$ & ND & ND & Vulva & ND & $(-)$ & ND & ND & \\
\hline 14 & $\mathrm{R}$ & I & $(+)$ & $(+)$ & ND & $(+)$ & Vulva & ND & $(-)$ & ND & $(-)$ & \\
\hline 15 & $\mathrm{R}$ & III & $(+)$ & $(+)$ & ND & ND & Vulva & ND & $(-)$ & ND & ND & \\
\hline 16 & $\mathrm{R}$ & 1 & $(+)$ & $(+)$ & ND & ND & Vulva & ND & $(-)$ & ND & ND & \\
\hline 17 & TR & III & $(+)$ & $(+)$ & ND & ND & Vulva & ND & $(+)$ & ND & ND & IL, IN, ST (thigh) \\
\hline 18 & TR & III & $(+)$ & $(+)$ & $(+)$ & ND & Vulva & $(+)$ & $(+)$ & $(-)$ & ND & IL, IN \\
\hline 19 & TR & III & $(+)$ & $(+)$ & ND & ND & Vulva & $(+)$ & $(+)$ & ND & ND & IL, IN, lung \\
\hline 20 & TR & III & $(+)$ & $(+)$ & $(+)$ & ND & Vulva & $(+)$ & $(+)$ & $(-)$ & ND & IN \\
\hline
\end{tabular}

R: restaging; TR: treatment response; PET: positron emission tomography; CT: computed tomography; MRI: magnetic resonance imaging; (-): negative for malignancy; ND: not done; (+): positive for malignancy; IL: iliac lymph nodes; IN: inguinal lymph nodes; ST: subcutaneous tissue 
A

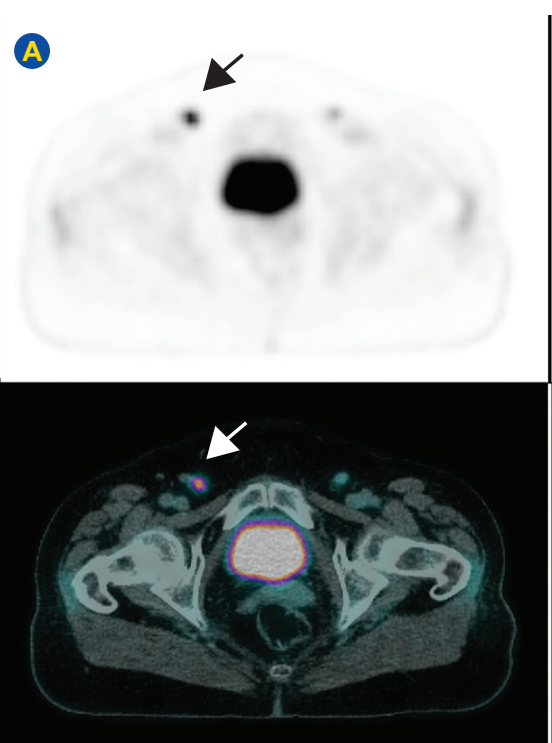

B
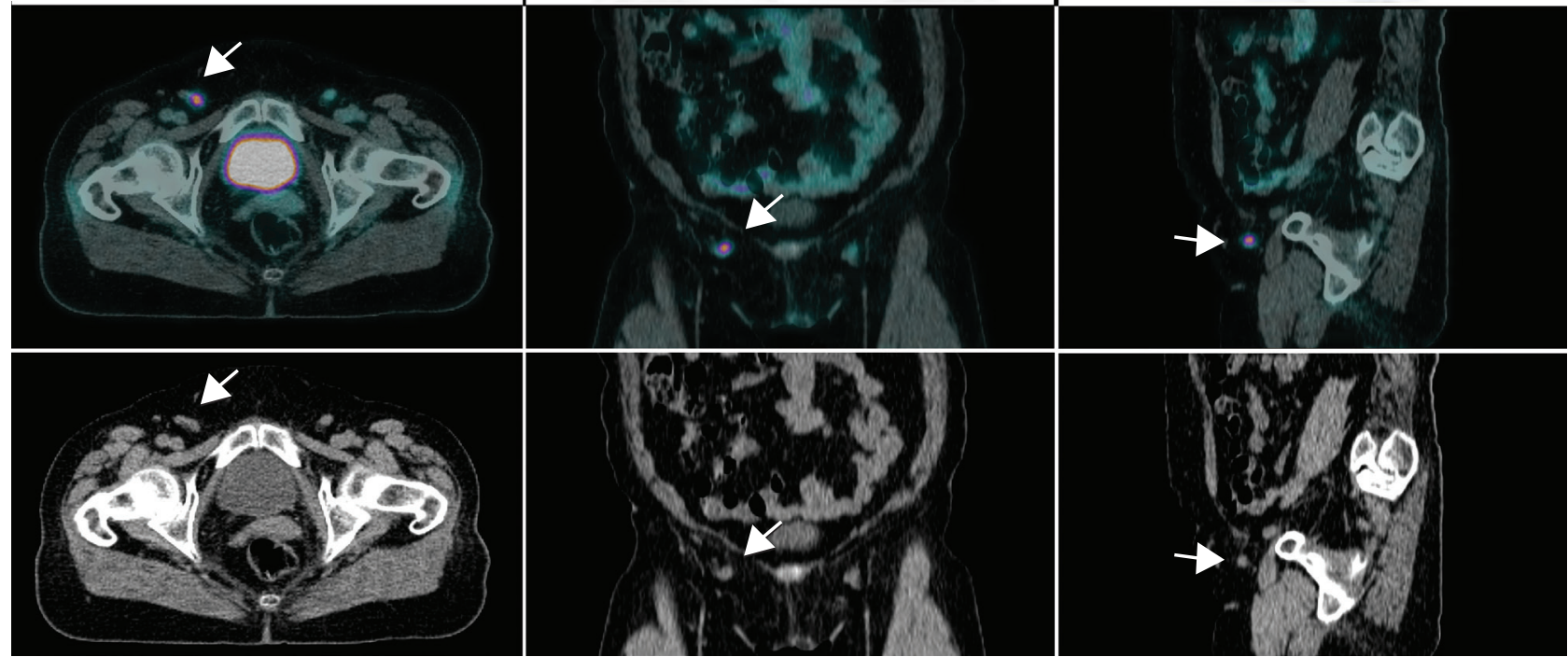

Figure 3 - 18F-FDG-avid metastatic inguinal lymph node (arrows on PET, PET/CT and CT in axial A, coronal B, and sagittal C planes)

PET/CT were not detected as suspicious by CT. Biopsy was carried out in two of these patients and confirmed malignancy in both. MRI studies were in agreement with $18 \mathrm{~F}-\mathrm{FDG}$ $\mathrm{PET} / \mathrm{CT}$ in all cases $(3 / 3)$.

\section{DISCUSSION}

In our study, 18F-FDG PET/CT identified abnormalities (main lesion/metastatic lymph nodes) more often than conventional CT scans in recurrent disease. In comparison with histology, 18F-FDG PET/CT had a sensitivity of $95 \%$ and a positive predictive value (PPV) of $100 \%$ in identifying the primary tumour and the recurrent main lesion. The sensitivity and PPV of 18F-FDG PET/CT in detecting metastasis was not determined because of the lack of histology data.

In the current literature, there is scarce data available on the usefulness of 18F-FDG PET/CT in the management of vulvar and vaginal cancer.

Cohn et al reported that 18F-FDG PET/CT had $80 \%$ sensitivity, $90 \%$ specificity and a PPV of $80 \%$ in identifying vulvar cancer lymph node metastasis. ${ }^{9}$ Given the high specificity, it is postulated that 18F-FDG PET/CT can be used to locate metastatic nodes and assess response to radiation prior to groin dissection. Furthermore, 18F-FDG $\mathrm{PET} / \mathrm{CT}$ has the potential of identifying metastatic disease in pelvic lymph nodes, which can be useful to prevent extensive groin dissection and treat alternatively with chemoradiation. ${ }^{10}$ Kamran et al found that 18F-FDG PET/CT had $50 \%$ sensitivity, $100 \%$ specificity, a PPV of $100 \%$, and a negative predictive value (NPV) of $57 \%$ in detecting meta- static groin lymph nodes in patients with vulvar cancer. ${ }^{11}$ The high PPV supports the notion that 18F-FDG PET/CT imaging can be used for treatment planning preceding surgical staging and to adequately plan preoperative chemoradiation therapy. However, owing to low sensitivity, a negative scan result does not preclude surgical resection. On the other hand, Dolanbay et al demonstrated a sensitivity, specificity, PPV and a NPV of $100 \%$ in identifying inguinofemoral lymph node metastases in patients with vulvar cancer. ${ }^{12}$ In a prospective study of 23 patients, Lamoreaux et al demonstrated that 18F-FDG PET/CT detected all metabolically active primary vaginal tumour with a sensitivity of $100 \%$ and detected metastatic lymph nodes more often than conventional CT scans. ${ }^{13}$

Lin et al studied 23 women with vulvar cancer and concluded that $18 \mathrm{~F}-\mathrm{FDG}$ PET/CT imaging may have a positive impact on patient management. ${ }^{14} \mathrm{~A}$ recent study in patients with vulvar cancer reported that preoperative 18F-FDG $\mathrm{PET} / \mathrm{CT}$ changed the therapeutic management in $61.5 \%$, although inflammatory lymph nodes may also be $18 \mathrm{~F}-\mathrm{FDG}$ avid on 18F-FDG PET/CT scanning and can result in falsepositive results, whereas necrotic lymph nodes may not be metabolically active and can cause false-negative results. ${ }^{15}$ Robertson et al reported a change in patient management in $36 \%$ of patients with primary or recurrent vaginal and vulvar cancer after $18 \mathrm{~F}-\mathrm{FDG}$ PET/CT. ${ }^{16}$

Our findings reinforce the usefulness of this technique in vulvar and vaginal cancer.

There are a number of limitations in our study. The 
retrospective cross-sectional design of this study precludes causal inference. The small sample size and the lack of comparative imaging tests (due to the rarity of vulvar and vaginal cancer) represent additional limitations. In an ideal comparison, all patients would have undergone 18F-FDG PET/CT and whole-body conventional CT imaging and/or $\mathrm{MRI}$, using histopathology data as the reference standard. The sensitivity, specificity, PPV and Negative Predictive Value (NPV) of 18F-FDG PET/CT in identifying metastasis could then be evaluated. Finally, the use of two PET/CT systems could have interfered in image analysis and influenced the SUVmax calculation concerning the main lesion.

\section{CONCLUSION}

Our study showed that 18F-FDG PET/CT can be a useful tool in patients with vulvar and vaginal cancers, namely in defining the extent of disease and contributing to an accurate staging and restaging. However, further studies, namely prospective multicenter studies, are necessary to define this role.

\section{AUTHORS CONTRIBUTIONS}

PG: Data acquisition and analysis, literature research, draft of the manuscript.

\section{REFERENCES}

1. Siegel RL, Miller KD, Jemal A. Cancer statistics, 2018. CA Cancer J Clin. 2018;68:7-30

2. Lai J, Elleray R, Nordin A, Hirschowitz L, Rous B, Gildea C, et al. Vulval cancer incidence, mortality and survival in England: age-related trends. BJOG. 2014;121:728-38

3. Wu X, Matanoski G, Chen VW, Saraiya M, Coughlin SS, King JB, et al. Descriptive epidemiology of vaginal cancer incidence and survival by race, ethnicity, and age in the United States. Cancer. 2008;113:2873-82.

4. Hacker NF, Eifel PJ, van der Velden J. Cancer of the vulva. Int J Gynaecol Obstet. 2015;131:76-83.

5. Hacker NF, Eifel PJ, van der Velden J. Cancer of the vagina. Int J Gynaecol Obstet. 2015;131:84-7.

6. Brincat MR, Muscat Baron Y. Sentinel lymph node biopsy in the management of vulvar carcinoma: an evidence-based insight. Int J Gynecol Cancer. 2017;27:1769-7.

7. Bhosale $P$, lyer $R$, Jhingran A, Podoloff D. PET/CT imaging in gynecologic malignancies other than ovarian and cervical cancer. PET Clin. 2010;5:463-75.

8. Rockall AG, Cross S, Flanagan S, Moore E, Avril N. The role of FDG $\mathrm{PET} / \mathrm{CT}$ in gynaecological cancers. Cancer Imaging. 2012;12:49-65.

9. Cohn DE, Dehdashti F, Gibb RK, Mutch DG, Rader JS, Siegel BA, et al. Prospective evaluation of positron emission tomography for the detection of groin node metastases from vulvar cancer. Gynecol Oncol. 2002;85:179-84

10. Rogers LJ, Howard B, Howells RE. Chemoradiation in advanced vulval
ASP, SN: Data acquisition, critical review of the manuscript.

LV: Data acquisition, draft and critical review of the manuscript.

RT: Data analysis, critical review of the manuscript.

AP, LHD: Critical review of the manuscript.

\section{PROTECTION OF HUMANS AND ANIMALS}

The authors declare that the procedures were followed according to the regulations established by the Clinical Research and Ethics Committee and to the Helsinki Declaration of the World Medical Association update on 2013.

\section{DATA CONFIDENTIALITY}

The authors declare having followed the protocols in use at their working center regarding patients' data publication.

\section{CONFLICTS OF INTEREST}

All authors report no conflict of interest.

\section{FUNDING SOURCES}

This research received no specific grant from any funding agency in the public, commercial, or not-for-profit sectors.

carcinoma. Int J Gynecol Cancer. 2009;19:745-51.

11. Kamran MW, O'Toole F, Meghen K, Wahab AN, Saadeh FA, Gleeson N. Whole-body [18F]fluoro-2-deoxyglucose positron emission tomography scan as combined PET-CT staging prior to planned radical vulvectomy and inguinofemoral lymphadenectomy for squamous vulvar cancer: a correlation with groin node metastasis. Eur J Gynaecol Oncol. 2014;35:230-5

12. Dolanbay M, Ozcelik B, Abdulrezzak U, Serin IS, Kutuk MS, Uludag S. F-18 fluoro-D-glucose (FDG)-positron emission tomography (PET)/ computed tomography (CT) in planning of surgery and sentinel lymph node screening in vulvar cancers. Arch Gynecol Obstet. 2016;293:131924

13. Lamoreaux WT, Grigsby PW, Dehdashti F, Zoberi I, Powell MA, Gibb RK, et al. FDG-PET evaluation of vaginal carcinoma. Int J Radiat Oncol Biol Phys. 2005;62:733-7.

14. Lin G, Chen CY, Liu FY, Yang LY, Huang HJ, Huang YT, et al. Computed tomography, magnetic resonance imaging and FDG positron emission tomography in the management of vulvar malignancies. Eur Radiol. 2015;25:1267-78.

15. Peiró V, Chiva L, González A, Bratos R, Alonso S, Márquez R, et al. Utility of the PET/CT in vulvar cancer management. Rev Esp Med Nucl Imagen Mol. 2014;33:87-92.

16. Robertson NL, Hricak H, Flanagan S, Moore E, Avril N. The impact of FDG PET/CT in the management of patients with vulvar and vaginal cancer. Gynecol Oncol. 2016;140:420-4.17. 